\title{
ANTIBIOTIK PROFILAKSIS PADA PENYAKIT JANTUNG
}

\author{
Musa Ghufron, Muhammad Perdana Airlangga \\ Fakultas Kedokteran Universitas Muhammadiyah Surabaya \\ Surabaya
}

\begin{abstract}
Infective endocarditis (IE) is an uncommon but lifethreatening infection. Despite advances in diagnosis, antimicrobial therapy, surgical techniques, and management of complications, patients with IE still have high morbidity and mortality rates related to this condition. Since the last American Heart Association (AHA) publication on prevention of IE in 1997, many authorities and societies, as well as the conclusions of published studies, have questioned the efficacy of antimicrobial prophylaxis to prevent IE in patients who undergo a dental, gastrointestinal (GI), or genitourinary (GU) tract procedure and have suggested that guidelines should be revised
\end{abstract}

Keywords : infective endocarditis, prophylaxis antibiotic

\section{PENDAHULUAN}

Infective endocarditis (IE) merupakan kelainan serius yang berhubungan dengan angka mortalitas dan morbiditas yang tinggi. Pencegahan dengan pemberian antibiotik profilaksis pada tindakan-tindakan yang menyebabkan timbulnya bakteriemia sangat diperlukan. Penelitian eksperimental menunjukkan kerusakan endotel dapat memicu deposit platelet dan fibrin serta pembentukan lesi trombotik non-bakterial pada endokard. Pada kondisi dimana terjadi bakteremia, organisme dapat menempel pada lesi di endokard dan dapat berkembang biak di antara kompleks platelet-fibrin yang menyebabkan vegetasi. Kelainan katup dan kongenital terutama yang berkaitan dengan high velocity jets dapat menyebabkan kerusakan endotel. Sejak tahun 1955, AHA membuat rekomendasi mengenai pencegahan endokarditis dengan antibiotik profilaksis sebelum tindakan-tindakan di bidang dental, gastrointestinal, dan genitourinaria pada pasien-pasien yang beresiko. Namun, efikasi antibiotik profilaksis sendiri masih menjadi pertanyaan apakah dapat mengurangi insiden IE, sehingga penggunaannya masih menjadi kontroversi $1^{1,2}$.

\section{EPIDEMIOLOGI}

Epidemiologi IE mengalami perubahan selama beberapa tahun terakhir, terutama pada negara berkembang. Dahulu, IE sering dijumpai pada dewasa muda dengan riwayat penyakit jantung katup (sebagian besar berasal dari Rheumatic Heart Disease), namun saat ini IE sering dijumpai pada usia lanjut, baik dengan riwayat penyakit jantung katup sebelumnya maupun riwayat pemakaian katup prostetik sebelumnya. Penelitian skala besar pada 2371 kasus IE di 7 negara (Denmark, Perancis, Italia, Belanda, Swedia, UK dan USA) menunjukkan adanya peningkatan insiden IE yang berhubungan dengan katup prostetik dan prolaps katup mitral dan penurunan insiden IE yang disebabkan Rheumatic heart disease ${ }^{1,3}$.

Insiden IE berkisar antara 3-10 kasus dari 100.000 pasien bervariasi dari masingmasing negara. Insiden IE menurun pada 
dewasa muda dan meningkat seiring dengan bertambahnya umur (kasus terbanyak 14,5 kasus dari 100.000 pasien per tahun pada usia 70-80 tahun). Pada semua studi epidemiologi kasus IE, rasio terbanyak pria : wanita $2: 1$, meskipun fenomena tersebut belum dapat dijelaskan. Namun, pasien wanita memiliki prognosis lebih buruk dan jarang memerlukan tidakan pembedahan dibandingkan dengan pasien pria ${ }^{1}$.

\section{FAKTOR PREDISPOSISI}

Faktor predisposisi terbaru penyebab IE telah bermunculan antara lain riwayat katup prostetik, katup yang mengalami degenerasi, dan pemakaian obat-obat intravena yang berkaitan dengan peningkatan resiko bakteremia. Dari 3784 kasus IE, mikroorganisme penyebab utama adalah grup staphylococci sedangkan penyebab terbanyak kedua adalah grup streptococci. Pada negara berkembang, sebagian besar kasus IE masih disebabkan oleh Rheumatic heart disease, dan mikroorganisme terbanyak masih disebabkan oleh grup streptococci. Dan juga, variasi geografis ikut berperan. Sebagai perbandingan, angka kejadian IE yang disebabkan oleh $S$. aureus di USA meningkat. Hal ini disebabkan oleh 3 faktor utama antara lain hemodialisis lama, diabetes mellitus dan pemasangan alat intravaskular. Sedangkan di negara lain, faktor predisposisi S. Aureus disebabkan oleh penyalahgunaan obat-obat IV ${ }^{1,4}$.

Secara garis besar, faktor predisposisi terjadinya IE dibagi menjadi dua :

1. Faktor Kardiak; Pasien dengan kelainan jantung katup, atau memakai katup jantung buatan beresiko terkena IE. Pasien yang memakai katup bioprostetik maupun mekanik memiliki resiko yang terdiri dari 2 fase, Early PVE (muncul antara 1 tahun setelah pemasangan) disebabkan oleh karena infeksi nosokomial dan mikroorganisme penyebabnya lebih bervariasi dibandingkan Late PVE, yang biasanya disebabkan karena community acquired. Kedua fase tersebut samasama memiliki resiko tinggi terjadinya IE. Secara keseluruhan, pasien dengan katup prostetik memiliki resiko terjadinya IE 5-10 kali dibandingkan katup alami dan 7-25\% kasus terjadi di negara berkembang. Penyakit jantung kongenital juga merupakan faktor resiko IE, tidak hanya karena peningkatan turbulensi lesi kongenital yang memicu kerusakan endotel, namun juga karena beberapa pasien jantung bawaan sebelumnya telah dilakukan tindakan pembedahan. Pada penelitian skala besar pada pasien pediatri, kelainan jantung bawaan yang paling sering menimbulkan IE adalah VSD, tetralogy of fallot (TOF) dan aorta stenosis. Katup aorta bicuspid merupakan kelainan bawaan terbanyak dengan insiden 0,9-2 \% pada populasi dewasa.

2. Faktor non kardiak; dibagi mejadi 4 kelompok: a. Faktor-faktor yang dapat mempermudah terjadinya NBTE, termasuk leukemia, sirosis hepatis, hypercoagulabilty state, inflammatory bowel disease, systemic lupus erithematosus dan pemberian steroid.

b. Pertahanan tubuh host yang lemah, baik humoral (ex. Steroid) atau selular. Infeksi HIV secara independen meningkatkan resiko IE terutama pada 
kelompok penyalahgunaan obat intravena.

c. Pertahanan tubuh lokal non imun terganggu seperti peningkatan permeabilitas transmucosal yang berhubungan dengan inflammatory bowel disease dan penurunan klirens bakteri seperti pada pasien hemodialisis dengan AV fistula.

d. Peningkatan frekuensi bakteri dari perlukaan kulit (ex. luka bakar, ulkus dekubitus) ${ }^{5}$.

\section{PATOFISIOLOGI}

Endokarditis terjadi oleh karena interaksi kompleks antara host (endotel katup, sistem imun, mekanisme hemostasis, anatomi jantung), mikroorganisme yang menginfeksi (apakah memproduksi toksin dan enzim), dan kejadian yang dapat menyebabkan bakteremia ${ }^{6}$.

\section{ENDOTEL KATUP}

Endotel katup normal resisten terhadap kolonisasi dan infeksi yang disebabkan oleh bakteri yang beredar di dalam darah. Penelitian pada hewan coba menunjukkan kerusakan endotel merupakan awal terjadinya IE. Kerusakan endotel dapat terjadi melalui proses inflamasi atau mekanis. Inflamasi katub terjadi secara asimptomatis. Lebih dari $25 \%$ pasien degenerasi katup berusia $>40$ tahun didapatkan mikro ulserasi dan inflamasi lokal. Kerusakan secara mekanis berupa jet lession yang juga merusak endotel. Hal ini dibuktikan melalui penelitian pada daerah vegetasi yang ternyata sama dengan blood flow injur. Seperti contohnya, daerah anterior mitral leaflet pada kelainan Aorta
Regurgitasi, dinding atrium kiri pada Mitral Regurgitasi, septal leaflet ricuspid pada VSD. Kerusakan endotel tersebut mencetuskan deposisi platelet dan fibrin pada permukaan endotel, yang akhirnya terjadi pembentukan Non Bacterial Thrombotic Endocarditis (NBTE) ${ }^{6}$.

Sel endotel, fibroblast dan platelet pada lesi endotel akan menghasilkan fibronectin yang bertindak sebagai jembatan untuk memudahkan perlekatan bakteri dan akhirnya masuk ke dalam sel host dan membuat vegetasi. Beberapa bakteri mempunyai microbal surface components recognizing adhesive matrix mollecules (MSCRAMMs) yang berfungsi untuk melekatkan pada permukaan endotel katup. Contohnya, streptococci yang memproduksi glycans dan dextran. Sekali masuk ke dalam sel, streptococci dan bertahan hidup, terlindungi dari antibiotik dan pertahanan tubuh host. Dan juga, stapbylococci dan streptococci dapat mengaktifkan clotting cascade yang mengakibatkan bakteri semakin virulen. Konsentrasi tinggi bakteri (108-109 bakteri per gram jaringan) dapat berkumulasi diantara vegetasi. Menariknya, Staphylococcus aureus dapat mempproduksi tissue factor yang menjelaskan mengapa mikroorganisme tersebut dapat menempel pada katup yang relatif normal ${ }^{5,6}$.

Siklus endokarditis mulai dari perlekatan, pertumbuhan organisme, dan deposisi platelet-fibrin terjadi berulang sampai terjadi pembesaran vegetasi. Berbagai cara ditempuh untuk memutus siklus terutama untuk mencegah mikroorganisme menempel katup prostetik dengan cara melapisi katup prosteitik yang dinamakan silver coated polyster ring. Namun sayangnya, cara tersebut meningkatkan kejadian peri-valvular leak dan emboli. Meskipun 
pemberian antibiotik adekuat, beberapa vegetasi steril sendiri masih ada. Pertumbuhan vegetasi yang semakin membesar dapat menyebabkan perforasi dari leaflet, dan akhirnya menyebabkan ruptur chordae. IE juga dapat meluas ke sekitar katub seperti di anulus, sinotubular juncton, miokard maupun sitem konduksi6.

\section{BAKTEREMIA}

Peranan bakteremia telah diteliti pada hewan coba dengan memasukkan kateter melalui vena femoralis dengan tujuan memicu terjadinya NBTE. Faktor-faktor seperti besarnya bakteremia maupun kemampuan patogen berperan penting dalam menimbulkan kerusakan katup. Bakteremia tidak hanya muncul setelah tindakan invasif tetapi juga pada kegiatan mengunyah dan menggosok gigi. Kemungkinan bakteremia spontan sangat kecil dan durasinya pendek (1-100 colony forming unit (cfu)/ml selama 10 menit), sehingga dapat menjelaskan insiden tinggi sebagian besar kasus IE tidak berkaitan dengan tindakan invasif. Durasi dari bakteremia sampai terjadi gejala klinis IE biasanya antara 714 hari pada kelompok viridans, streptococci, atau enterococci ${ }^{1,7}$.

\section{MIKROBA PATOGEN}

\section{COCCUS GRAM POSITIF}

Streptococci Viridans, merupakan penyebab terbanyak community-acquired IE. Meskipun respon dengan terapi medikamentosa, mikroorganisme ini sering diterapi dengan pembedahan.

Streptococcus Beta-Hemolyticus, termasuk enterococci dan streptococcus bovis. Enterococci merupakan kuman flora normal pada saluran pencernaan dan kadang-kadang muncul pada urethra anterior, dan biasanya menyerang usia lanjut dengan faktor komorbid yang berhubungan dangen infeksi saluran kencing dengan riwayat pemasangan kateter urine. Enterococcal IE sering menimbulkan komplikasi gagal jantung.

Staphylococci (coagulase-positif dan coagulasenegatif), merupakan mikroorganisme penyebab dari 30-40\% kasus IE, dan sebagian besar kasus karena $\mathrm{S}$ aureus coagulase-positif. Mikroorganisme ini merupakan penyebab terbanyak kasus IE akut. Peningkatan proporsi IE karena $\mathrm{S}$ aureus berkaitan dengan kontak melalui tindakan medis. Pada penelitian kohort 922 kasus IE, S aureus merupakan penyebab tersering IE sebanyak $36 \%$ dan diantara kasus S aureus coagulase-positif, $46 \%$ berkaitan dengan tindakan medis. $\mathrm{S}$ aureus berhubungan dengan peningkatan resiko komplikasi IE seperti stroke, emboi sistemik dan bakteremia persisten, tetapi dengan resiko yang sama terjadi abses intracardiac dan gagal jantung. Meskipun komplikasi tinggi, rata-rata jarang dilakukan tindakan pembedahan dibandingkan penyebab lain.

Meskipun staphylococci coagulasenegatif, terutama Staphylococcus epidermidis merupakan penyebab utama endokarditis katup prostetik, namun juga dapat terjadi sebagai penyebab endokarditis katup alami, dan berhubungan dengan tindakan medis dan meskipun angka komplikasi sama dengan $\mathrm{S}$ aureus coagulase-positif, angka resiko dilakukan tindakan pembedahan lebih besar. Kasus IE yang disebabkan oleh staphylococci koagulase negatif lainnya adalah Staphylococcus lugdunesis, merupakan kuman penyebab IE 
yang lebih virulen daripada bentuk staphylococci gram negatif lainnya, dengan angka morbiditas yang tinggi, meskipun secara invitro respon terhadap sebagian besar antibiotik termasuk penicilin dan cephalosporin. Strain ini sering salah diidentifikasikan dengan $\mathrm{S}$ aureus ${ }^{6}$.

HACEK

Mikroorganisme yang termasuk kelompok HACEK (Hemophilus, Actinobacillus, Cardiobacterium, Eikenella, Kingella merupakan bakteri-bakteri yang pertumbuhannya lambat pada media kultur darah dan memerlukan inkubasi yang lama. Gejala klinis antara lain vegetasi besar, kejadian emboli yang berulang, timbulnya gagal jantung kongestif dan kadang-kadang diperlukan tindakan pembedahan ${ }^{6}$.

JAMUR

Sebagian besar pasien dengan endokarditis yang disebabkan oleh jamur dibagi menjadi 3 kelompok : (1) Ketergantungan narkotika (2) Pasien yang baru menjalani pembedahan jantung rekonstruktif dan (3) pasien immunocompromised terutama setelah menjalani transplantasi organ. Candida albicans merupakan penyebab terbanyak. Bukti-bukti terbaru menunjukkan tejadi peningkatan kasus IE fungal yang disebabkan tindakan medis. Pada 152 kasus antara tahun 1995-2000, Intravenous drug user (IDU) hanya 4,1\% kasus IE, sedangkan faktor predisposisi lainnya seperti kelainan jantung (47,3\%), katup prostetik (44,6\%), dan pemakaian central venous catheter (CVP). Pada kasus IE dengan komplikasi terutama kejadian emboli dan gagal jantung, umumnya terjadi pada IE fungal dan tindakan pembedahan dilakukan pada 2/3 kasus. Angka mortalitas sangat tinggi
(56,6\%). Peneitian lain menyebutkan IE fungal memiliki angka komplikasi yang tinggi terutama abses miokard dan bakteremia persisten ${ }^{6}$.

\section{MIKROORGANISME LAIN}

IE yang disebabkan oleh Coxiella burnetti (penyebab Q fever) biasanya berlangsung kronis dengan gejala flu-like symptom yang muncul 6-12 bulan sebelumnya. Biasanya ada jeda waktu lama dari mulainya gejala sampai diagnosis IE karena berbentuk endocarditis "negative culture". Endokarditis pada katup aorta umumnya disebabkan oleh bakteri ini pada sebagian besar kasus. Diagnosis terbaik berdasarkan pemeriksaan serologis.yaitu peningkatan tier antibody pada antigen fase I diukur dengan fiksasi komplemen atau ELISA yang merupakan tanda infeksi kronis dimana penigkatan titer antibodi pada antigen fase II yang merupakan tanda infeksi masih aktif. Peningkatan titer antibody fase I ( $\operatorname{IgG}$ dan atau IgA) > 1:200 merupakan diagnostik Q fever endocarditis dan berguna sebagai tindak lanjut respon terhadap terapi ${ }^{6}$.

\section{ENDOKARDITIS KULTUR NEGATIF}

Kultur darah negative terjadi pada 5-10 $\%$ kasus IE melalui kriteria diagnostik yang ketat. Hal ini terjadi karena beberapa faktor : (1) Pemberian antibiotik sebelumnya (2) Kultur diambil pada akhir fase kronis ( $>5$ bulan) (3) Uremia pada kasus kronis (4) Endokarditis mural pada Ventricular septal defect, post IMA, infeksi pada kawat pacemaker, (5) Pertumbuhan mikroorganisme yang berlangsung lambat seperti kuman anaerob (6) Endokarditis subakut pada jantung kanan (7) Endokarditis fungal dan (8) Endokarditis yang disebabkan oleh parasit 
intraselular obligat rickettsiae, chlamydiae, dan Tropheryma whippelli'.

\section{KONTROVERSI ANTIBIOTIK PROFILAKSIS PADA IE}

AHA sudah membuat guidelines antibiotik profilaksis sebagai pencegahan IE selama lebih dari 50 tahun. Pada tahun 1955, guidelines pertama dibuat dan penicilin merupakan antibiotik pertama.Namun, 5 tahun kemudian AHA memberikan peringatan adanya resistensi terhadap penicilin akibat penggunaan jangka panjang antibiotik profilaksis terutama pasien pediatri, dan Chloramphenicol direkomendasikan jika alergi terhadap penicilin. Tahun 1965, antibiotik profilaksis harus diberikan sebelum tindakan invasif pada saluran pencernaan dan saluran kemih. Pada tahun 1997, AHA membagi kelainan jantung menjadi high, moderate dan low risk, dan yang tidak perlu diberikan antibiotik profilaksis adalah low risk.10 tahun kemudian, guidelines IE mengalami evolusi dimana hanya high risk yang perlu diberikan antibiotik profilaksis. Guidelines ESC mengenai IE yang terbaru tahun 2009 dan The British Society of Antimicrobal Chemoteraphy juga merekomendasikan pemberian antibiotik profilaksis pada resiko tinggi. Sedangkan NICE (National Institute for Health and Clinical Excellence) tidak merekomendasikan penggunaan antibiotik profilaksis pada semua kelainan jantung $8^{8,9,10,11}$.

$$
\text { Guidelines IE terbaru memicu }
$$
kontroversi di kalangan tenaga medis terutama dokter umum, dokter jantung, dokter gigi dan pasien. Di satu sisi, guidelines terbaru lebih praktis dan tidak menimbulkan salah interpretasi kelainan jantung dibandingkan guidelines sebelumnya. Tetapi, di sisi lain tenaga medis memiliki ketakutan yang wajar jika tidak memberikan antibiotik profilaksis meskipun guidelines terbaru memberikan perlindungan hukum yang kuat. Oleh karena itu, tenaga medis perlu mendiskusikan manfaat dan kerugian antibiotik profilaksis kepada pasien sebelum keputusan akhir dibuat ${ }^{1,12}$.

Guidelines IE sebelumnya hanya terbatas pada opini para ahli atau penelitian case control terbatas. Sedangkan guidelines IE saat ini berdasarkan data-data kolektif yang dipublikasikan selama 2 dekade9.

Beberapa alasan merevisi guidelines sebelumnya antara lain :

(1) IE lebih banyak disebabkan bakteremia oleh karena paparan yang berulang dibandingkan dengan tindakan invasif dental, saluran pencernaan maupun saluran kemih

Sebagian besar data-data tindakan invasif yang menyebabkan IE hanya berfokus pada tindakan dental, sedangkan tindakan invasif saluran pencernaan dan saluran kemih masih jarang. Bakteremia sering mncul pada manipulasi gigi dan jaringan periodontal. Beberapa frekuensi bakteremia oleh karena tindakan dental : ekstraksi gigi (10-100 \%), bedah periodontal (36-88\%), scaling dan perawatan saluran akar (8-80 \%) dan tindakan edondontic (> $20 \%$ ). Namun, bakteremia juga sering muncul pada aktivitas sehari hari seperti menyikat gigi (20-68\%), penggunaan tusuk gigi (20-40\%), dan mengunyah makanan (7-51\%). Jika megacu data statisitk bahwa penduduk Amerika Serikat mengunjungi dokter gigi ratarata 2 kali per tahun, maka frekuensi bakteremia 
sendiri paling banyak berasal dari aktivitas sehari-hari. Penelitian lain menunjukkan bahwa jumlah kuman yang menimbulkan bakteremia pada tindakan dental relatif rendah $\left(<10^{4}\right.$ CFUs bakteri/ $\mathrm{mL}$ ), sama dengan aktivitas sehari-hari, dibandingkan dengan jumlah bakteremia yang dapat menyebabkan IE pada hewan coba $\left(10^{6}-\right.$ $10^{8}$ CFUs bakteri/mL). Penelitian Roberts dkk menyatakan bahwa paparan kumulatif bakteremia selama 1 tahun dari aktivitas seharihari mencapai 5,6 juta lebih besar dari tindakan ekstraksi gigi. Sebagai contoh, menggosok gigi dua kali sehari mencapai 154.000 paparan kumulatif bakteremia ${ }^{12,13}$

\section{(2) Antibiotik profilaksis hanya mencegah}

\section{sebagian kecil kasus IE}

Resiko IE akibat tindakan dental pada populasi sangat kecil, diperkirakan 1 kasus IE dari 14 juta tindakan dental.Resiko kelainan jantung antara lain MVP 1:1,1 juta tindakan; CHD 1: 475.000; RHD 1:142.000; katup prostetik 1:114.000, dan riwayat IE sebelumnya 1:95.00012.

\section{(3) Resiko efek samping pemberian antibiotik profilaksis}

Efek samping ringan seperti gatal-gatal, diare dan gangguan pencernaan sering muncul pada penggunaan antibiotik. Efek samping anafilaksis yang fatal banyak terjadi pada penggunaan penicilin. Sehingga, AHA merekomendasikan penggunaan antibiotik ampicilin atau amoxcilin yang lebih aman sebagai pengganti penicilin. Reaksi anafilaksis akibat penggunaan cephalosporin dilaporkan 1 kasus dari 1 juta pasien. Dan dilaporkan juga 1 kasus Clostridium difficle akibat penggunaan clindamycin. Namun, penggunaan antibiotik yang tidak tepat sasaran dapat mencetuskan resistensi mikroorganisme. Frekuensi resisitensi grup streptococci dan enterococci semakin meningkat selama 2 dekade. Oleh karena itu, resistensi dapat dicegah dengan penggunaan antibiotik yang efektif?.

(4) Pemeliharaan gigi dan rongga mulut yang sehat dan higienis sehari-hari dapat mengurangi insiden bakteremia dan lebih penting daripada pemberian antibiotik profilaksis untuk tindakan dental

\section{GUIDELINES IE TERBARU}

(1) Pasien dengan resiko tinggi terjadinya IE

Dibagi menjadi 3 kategori antara lain : (lihat tabel 1)

a) Pasien dengan katup prostetik yang digunakan saat operasi penggantian katup. Kelompok ini memiliki resiko tinggi IE dan sering timbul kompikasi dibandingkan katup alami.

b) Pasien dengan riwayat IE sebelumnya. Kelompok ini juga memiliki resiko besar terjadinya IE baru, mortalitas tinggi dan memiliki insiden komplikasi yang lebih berat dibandingkan terkena IE pertama kali.

c) Pasien dengan penyakit jantung kongenital, khusunya dengan sianosis dan post operative paliaitive shunt, conduit atau prostesa yang lain, ESC merekomendasikan pemberian antibiotik profilaksis 6 bulan pertama setelah tindakan pembedahan tanpa defek residual sampai endotelisasi pada katup prostetik terbentuk. 
Meskipun guidelines AHA merekomendasikan pemberian antibiotik profilaksis pada resipien transplantasi jantung, namu tidak ada bukti kuat yang mendukung. Dan juga, meskipun resiko terjadinya IE pada resepien transplan jantung yang mengalami cardiac valvulopathy, kemungkinan timbul IE dari gigi dan mulut sangat rendah.

Antibiotik profilaksis

tidak direkomendasikan pada kelainan katup lainnya ( termasuk katup bikuspid aorta, mitral valve prolapse, dan aorta stenosis) ${ }^{1}$.

\begin{tabular}{|c|c|c|}
\hline Recommendations: prophylaxis & Class' $^{2}$ & Level' \\
\hline $\begin{array}{l}\text { Antibiotic prophylaxis should only be considered for patients at highest risk of IE } \\
\text { 1. Patients with a prosthetic valve or a prosthetic material used for cardiac valve repair } \\
\text { 2. Patients with previous IE } \\
\text { 3. Patients with congenital heart disease } \\
\text { a. cyanotic congenital heart disease, without surgical repair, or with residual defects, palliative shunts or conduits } \\
\text { b. congenital heart disease with complete repair with prosthetic material whether placed by surgery or by } \\
\text { percutaneous technique, up to } 6 \text { months after the procedure } \\
\text { c. when a residual defect persists at the site of implantation of a prosthetic material or device by cardiac surgery } \\
\text { or percutaneous technique }\end{array}$ & lla & C \\
\hline Antibiotic prophylaxis is no longer recommended in other forms of valvular or congenital heart disease & III & c \\
\hline
\end{tabular}

Tabel 1. Kelainan jantung resiko tinggi yang mendapatkan antibiotik profilaksis ${ }^{1}$

\section{(2) Tindakan medis resiko tinggi}

A. Tindakan Dental (lihat tabel 2)

Tindakan yang beresiko termasuk manipulasi gusi atau periapical atau merobek mukosa mulut (termasuk scaling dan perawatan saluran akar). Antibiotik profilaksis tidak dianjurkan pada tindakan dental yang lain. Target utama antibioik profilaksis pada tindakan ini adalah menghambat masuknya kuman streptococci di sekitar rongga mulut. Peningkatan resistensi pada kuman patogen ini belum dilaporkan

Antibiotik jenis flouroquinolon dan glycopeptide tidak dianjurkan karena belum terbukti efikasinya dan berpotensi menimbulkan resistensi.

B. Tindakan Medis Lainnya
1. Saluran Pernafasan; pasien yang akan dilakukan tindakan invasif pada saluran pernafasan untuk mengobati infeksi seperti drainase abses, harus diberikan antibiotik golongan anti-staphylococcal penicilin atau cephalosporin. Vancomycin diberikan jika tidak toleransi dengan golongan beta-laktam. Vancomycin dan golongan lainnya diberikan jika diketahui penyebabnya meybicilin-resistant strain of $S$. Aureus (MRSA)

2. Saluran Pencernaan dan Saluran Kemih; Pada kasus dimana untuk mencegah luka atau infeksi yang berhubungan dengan saluran pencernaan dan saluran kemih, dapat diberikan antibiotik 
golongan beta-laktam seperti ampicilin, amoxcilin atau vancomycin. Antibiotik vancomycin harus diberikan pada pasien yang tidak toleransi dengan beta-laktam. Jika infeksi disebabkan strain yang resisten terhadap enterococcus, sebaiknya dikonsulasikan pada ahli di bidang infeksi.

3. Kulit atau Muskuloskeletal; Pada kasus dimana terdapat luka pada kulit (termasuk abses di mulut), jaringan kulit maupun otot, dapat diberikan antibiotik yang melawan staphylococci dan streptococci bata-hemolitik sperti antistaphylococcal penicilin atau cephalosporin. Vancomycin atau clindamycin dapat diberikan pada pasien yang tidak toleransi dengan beta-laktam. Jika infeksi tersebut dicurigai berasal dari MRSA, vancomycin atau antibiotik lainnya dapat diberikan.

4. Penggunaan Tatoo dan Tindik; Tren yang t,sekarang banyak erjadi pada anak muda harus mendapat perhatian, terutama pada individu yang menderita penyakit jantung kongenital. Laporan kasus terjadinya IE setelah tindakan tindik dan tatoo semakin meningkat terutama tindik di bagian lidah. Saat ini belum ada data-data mengenai insiden IE setelah tindakan tersebut dan efikasi antibiotik sebagai pencegahan. Edukasi pada pasien yan beresiko terjadinya IE lebih utama dan sebaiknya menghindari tindakan tatoo maupun tindik. Jika sudah dilakukan, prosedur tindakan harus steril meskipun antibiotik profilaksis tidak direkomendasikan.

5. Pembedahan Jantung dan Pembuluh darah; Pasien yang akan dilakukan pemasangan katup prostetik atau tindakan memasukkan benda asing ke dalam pembuluh darah, pemberian antibiotik harus dipertimbangkan mengingat resiko terjadinya infeksi. Profilaksis dapat diberikan sebelum tindakan, dapat diulangi jika tindakan diperpanjang, dan diakhiri 48 jam setelah tindakan. Pemeriksaan gigi harus dilakukan 2 minggu sebelum pemasangan katup prostetik atau benda asing lainnya, meskipun tindakan tersebut harus segera dilakukan.

6. Tindakan Invasif Lainnya; $30 \%$ dari semua kasus IE berasal dari tindakan invasif seperti pemasangan kateter vena. Meskipun menimbulkan masalah kesehatan yang serius, pemberian antibiotik profilaksis secara rutin sebelum tindakan tidak direkomendasikan. Tindakan aseptik selama insersi dan manipulasi kateter vena dan selama tindakan berlangsung lebih utama dalam mengurangi angka infeksi ${ }^{1}$

\section{(3) REGIMEN OBAT YANG DIREKOMENDASIKAN}

Untuk profilaksis IE, ESC merekomendasikan pemberian amoksicillin dengan dosis 2 gram (jika penderita bisa minum per oral). Jika penderita alergi terhadap golongan penicillin maka bisa diberikan clindamycin 600 
mg. Semua obat tersebut merupakan dosis tindakan (lihat tabel 3). ${ }^{1}$ tunggal dan diberikan 30-60 menit sebelum

\begin{tabular}{|l|l|l|}
\hline Recommendations: prophylaxis & Class' & Level $^{b}$ \\
\hline $\begin{array}{l}\text { A-Dental procedures: } \\
\text { Antibiotic prophylaxis should only be considered for dental procedures requiring manipulation of the gingival or } \\
\text { periapical region of the teeth or perforation of the oral mucosa } \\
\begin{array}{l}\text { Antibiotic prophylaxis is not recommended for local anaesthetic injections in non-infected tissue, removal of } \\
\text { sutures, dental X-rays, placement or adjustment of removable prosthodontic or orthodontic appliances or braces. } \\
\text { Prophylaxis is also not recommended following the shedding of deciduous teeth or trauma to the lips and oral mucosa }\end{array}\end{array}$ & III \\
\hline $\begin{array}{l}\text { B- Respiratory tract procedures": } \\
\text { Antibiotic prophylaxis is not recommended for respiratory tract procedures, including bronchoscopy or } \\
\text { laryngoscopy, transnasal or endotracheal intubation }\end{array}$ & C \\
\hline $\begin{array}{l}\text { C- Gastrointestinal or urogenital procedures": } \\
\text { Antibiotic prophylaxis is not recommended for gastroscopy, colonoscopy, cystoscopy or transoesophageal } \\
\text { echocardiography }\end{array}$ & III & C \\
\hline $\begin{array}{l}\text { D-Skin and soft tissue*: } \\
\text { Antibiotic prophylaxis is not recommended for any procedure }\end{array}$ & \\
\hline
\end{tabular}

Tabel 2. Tindakan invasif yang memerlukan antibiotik profilaksis ${ }^{1}$

\begin{tabular}{|c|c|c|c|}
\hline \multicolumn{2}{|c|}{} & \multicolumn{2}{|c|}{ Single dose 30-60 minutes before procedure } \\
\hline Situation & Antibiotic & Adults & Children \\
\hline No allergy to penicillin or ampicillin & Amoxicillin or ampicilin* & 2 g p.0. or i.v. & 50 mg/kg p.0. or i.v. \\
\hline Allergy to penicillin or ampicillin & Clindamycin & 600 mg p.o. or i.v. & 20 mg/kg p.o. or i.v. \\
\hline
\end{tabular}

Tabel 3. Dosis regimen pemberian antibiotik profilaksis ${ }^{1}$

\section{DAMPAK GUIDELINES IE TERBARU}

DeSimone dkk tahun 2012 meneliti insiden IE di Minnesota, USA yang melibatkan 22 pasien dengan kelainan jantung setelah muncul guidelines IE tahun 2007, dan hasilnya insiden IE tidak meningkat, meskipun sampel yang diambil terbatas dan hanya pada tindakan dental ${ }^{14}$.

Hasil yang sama terjadi pada penelitian Duval dkk yang tergabung dalam AEPEI study
(Association pour l'Etude et la Prévention de l'Endocardite Infectieuse), dimana penelitian dilakukan di Perancis yang melibatkan 993 pasien IE dan membandingkan insiden IE tahun 1991, 1999, dan 2008. Dan hasilnya, insiden IE relatif sama dengan tahun sebelumnya. Menariknya, insiden IE yang disebabkan Staphylococcus aureus meningkat pada pasien tanpa kelainan katup. Sedangkan di Inggris yang menganut guidelines NICE, terjadi penurunan 
penggunaan antibiotik profilaksis sebesar 78,6 $\% 15,16$.

\section{KESIMPULAN}

Antibiotik profilaksis hanya diberikan pada pasien dengan resiko tinggi terjadinya IE yang akan menjalani tindakan dental yang bersiko tinggi. Kesehatan gigi dan mulut yang baik dan pemeriksaan gigi dan mulut secara berperan sangat penting dalam mengurangi resiko IE. Tindakan aseptik sangat penting dalam manipulasi tindakan kateter dan tindakan invasif lainnya untuk mengurangi angka kejadian IE yang disebabkan tindakan invasif.

\section{DAFTAR PUSTAKA}

1. Habib G, Hoen B, Tornos P, et al. Guidelines on prevention, diagnosis and treatment of infective endocarditis executive summary; the task force on infective endocarditis of the European society of cardiology. Eur Heart $J$ 2009;30:2369-2413.

2. Prendergast $\mathrm{BD}$. The changing face of infective endocarditis. Heart 2006;92(7):879-85.

3. Hill EE, Herijgers $P$, Claus $P$, Vanderschueren S, Herregods MC, Peetermans WE. Infective endocarditis: changing epidemiology and predictors of 6-month mortality: a prospective cohort study. Eur Heart J 2007;28:196203

4. Cabell CH Jr., Jollis JG, Peterson GE, Corey GR, Anderson DJ, Sexton DJ, Woods CW, Reller LB, Ryan T, Fowler VG Jr. Changing patient characteristics and the effect on mortality in endocarditis. Arch Intern Med 2002;162:90-94.

5. Hunter D, Pepper J. Infective Endocarditis. In: Griffiths M, Cordingley JJ, Price S ed. Cardiovascular Critical Care. WileyBlackwell;2010:347-346
6. Wang A, Cabell CA. Infective Endocarditis. In: Wang A, Bashore TM. Valvular Heart Disease. Humana Press;2009:475-498

7. Starkebaum M, Durack D, Beeson P. The "incubation period" of subacute bacterial endocarditis. Yale J Biol Med 1977;50(1):49-58.

8. Hutto C, Pallasch TJ, Gage TW, Levison ME, Peter G,Zuccaro G, Jr. Prevention of bacterial endocarditis: recommendations by AHA. Circulation 1997; 96:358-366.

9. Wilson W, Taubert KA, Gewitz M, et al. Prevention of infective endocarditis. Guidelines from the American Heart Association. A guideline from the American Heart Association Rheumatic Fever, Endocarditis, and Kawasaki Disease Committee, Council on Cardiovascular Disease in the Young, and the Council on Clinical Cardiology, Council on Cardiovascular Surgery and Anesthesia, and the Quality of Care and Outcomes Research Interdisciplinary Working Group. Circulation 2007;115

10. Gould FK, Elliott TS, Foweraker J, et al. Guidelines for the prevention of endocarditis: report of the Working Party of the British Society for Antimicrobial Chemotherapy. J Antimicrob Chemother 2006;57(6): 103542.

11. NICE. Prophylaxis Against Infective Endocarditis. 2008.

12. Prevention of infective endocarditis: Guidelines from the American Heart Association. JADA 2008;139(1):3S-24S.

13. Roberts GJ. Dentists are innocent! "Everyday" bacteremia is the real culprit: a review and assessment of the evidence that dental surgical procedures are a principal cause of bacterial endocarditis in children.Pediatr Cardiol 1999;20(5):317-25.

14. DeSimone DC, Tleyjeh, IM, Correa de Sa DD, et al. Incidence of infective endocarditis caused by viridans group streptococci before and after publication of the 2007 American Heart 
Association's Endocarditis Prevention Guidelines. Circulation 2012;126:60-64.

15. Duval $\mathrm{X}$ et al. Temporal trends in infective endocarditis in the context of prophylaxis guideline modifications: Three successive population-based surveys. J Am Coll Cardiol 2012 May 29; 59:1968.
16. Thornhill MH, Dayer MJ, Forde JM, et al. Impact of the NICE guideline recommending cessation of antibiotic prophylaxis for prevention of infective endocarditis: before and after study. BMJ 2011; 342:d2392 